\title{
Researchers criticize response to killer algae
}

Rex Dalton, San Diego

Concerns are being raised about initial efforts to combat the first outbreak on the American Pacific coast of an ecologically damaging marine alga, Caulerpa taxifolia, which has already wreaked havoc in the Mediterranean Sea.

Marine biologists are criticizing the absence of the comprehensive research programme that they say is needed to counter the C. taxifolia invasion in Carlsbad, on the Californian coast between Los Angeles and San Diego. They want such a programme to be implemented and managed by an independent scientific panel.

They also point to a number of mistakes in the response since the rapidly growing alga - whose fronds displace other species - was discovered in mid-June in a tidal lagoon. One specimen sent to Switzerland for molecular analysis was found to be worthless, and a visiting Dutch researcher was unable to obtain a sample.

C. taxifolia is the latest invasive species to strike at ecosystems around the world, creating fears of ecological and commercial damage. It is a green seaweed with fern-like fronds, and can grow at a daily rate of $8 \mathrm{~cm}$.

Susan Williams, the director of the Bodega Marine Laboratory, run by the University of California (UC) at Davis, says she fears a major opportunity is being lost. She wants to see tests of several control methods, along with more precise data collection.

Although Williams recently joined a technical advisory team of state, federal and private officials overseeing the eradication effort, she claims that her suggestions are being ignored. "I feel like I'm shouting into a hurricane," she says.

Alexandre Meinesz, a biology professor at the University of Nice-Sophia Antipolis and the author of Killer Algae (University of Chicago Press, 1999), which describes Europe's experience since the algae struck in 1988, supports Williams' criticisms. He says that the events at Carlsbad sound like "the beginning of my story".

Daniel Simberloff, an ecologist who directs the Institute for Biological Invasions at the University of Tennessee at Knoxville, is also worried about the lack of tests on methods and the delays in molecular analysis of the strain found in Carlsbad.

Greig Peters, a fisheries biologist with the California water quality board, which is leading the eradication effort, says that Williams' "expertise and input has been very valuable", but rejects her criticism: "We have a real cohesive team, responding as rapidly as possible."

Lars Anderson, a plant physiologist from the US Department of Agriculture (USDA), says "an interesting mix" of government offi-

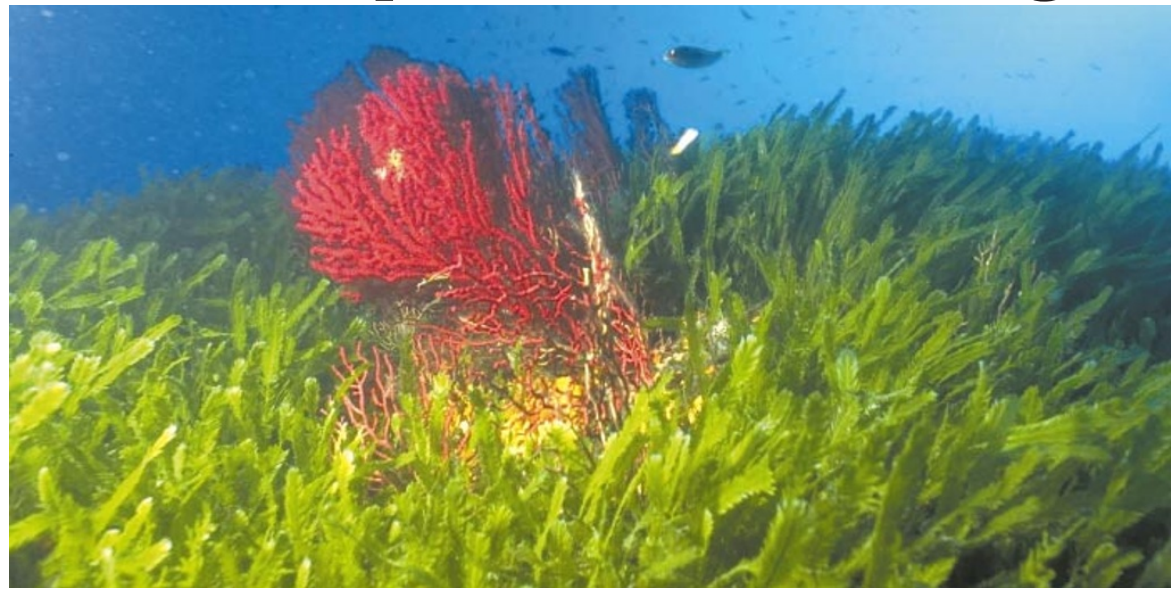

Deadly weed: fronds of Caulerpa taxifolia (green) threaten to smother marine ecosystems.

cials and academics has produced tension at a time when "we are not in a research mode".

"But if you stand back and look at other eradication efforts, this one gets high marks," says Anderson, who is playing a leading role in the eradication campaign from his USDA office at a weed-research facility at UC Davis.

There also are signs of a turf war over who fights the algae. Simberloff attempted to have Williams brief a meeting of the federal
Invasive Species Advisory Committee, of which he is a member, in Seattle this week. But the committee of experts advising 20 federal agencies is not expected to invite Williams to talk.

An invitation was seen as possibly offending another federal panel, the Aquatic Nuisance Species Task Force, that met this week in Vermont. Anderson is briefing that group on the Carlsbad experience.

\section{France may bid for fusion reactor}

Heather McCabe, Paris

Nuclear scientists and engineers are urging France to compete with Japan and Canada to host ITER (the International Thermonuclear Experimental Reactor), an international collaboration to further fusion research.

At present, there are two candidate sites, one at Clarington in Ontario, Canada, and the other in Japan. Sites in Sweden,

Germany and Italy have been discussed, but changing political circumstances mean that none of these are seen as viable.

The French Atomic Energy Commission has now suggested that ITER should be built at its Cadarache site near Aix-en-Provence. But the French government has yet to give the proposal its official backing.

The stumbling block will probably be money; it is sometimes assumed that the host country will pay $50-70 \%$ of ITER's estimated cost of at least 3.5 billion euros (US\$3.25 billion). Japanese officials have suggested that their nation would provide as much as two-thirds of the construction costs.

The ITER partners - Europe, Japan and Russia - have welcomed the French proposal. But France may not be favourite to host the reactor, even among Europeans,

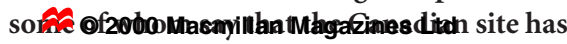
technical advantages. Some fusion

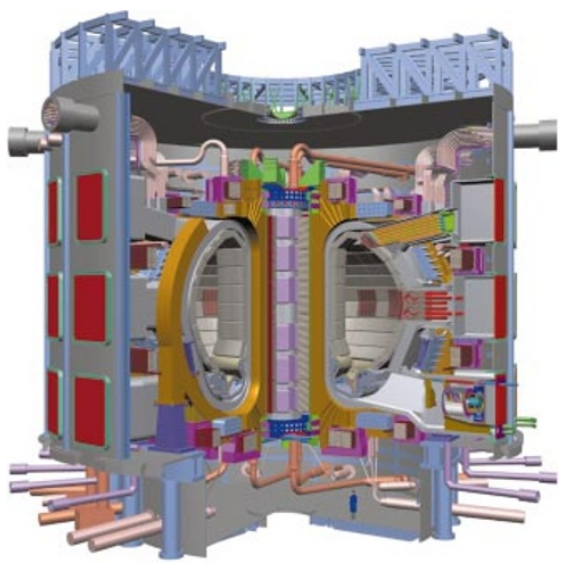

Defused? ITER could stay on the drawing board unless a host nation meets most of its costs.

researchers also hope that a Canadian site would lure the United States, which withdrew in 1999, back into the project.

ITER's next hurdle will be the budget discussions for the European Commission's sixth Framework programme of research at the beginning of next year. The project's supporters will have to convince the European Parliament to back ITER's current design proposal, but the parliament remains deeply divided on fusion energy. 